\title{
Kinetic of Biomass Growth and Protein Formation on Rice Bran Fermentation Using Rhizopus oryzae
}

\author{
Andhika Sukma $^{1}$, Bakti Jos ${ }^{2}$, and Siswo Sumardiono ${ }^{2 *}$ \\ ${ }^{1}$ Master Program in Chemical Engineering, Faculty of Engineering, Diponegoro University, Indonesia \\ ${ }^{2}$ Department of Chemical Engineering, Faculty of Engineering, Diponegoro University, Indonesia
}

\begin{abstract}
Rice bran is the outermost part of the rice grain wrapped in rice husks. Rice bran contains macro and micro nutrients that are bound to fibers that affect psychochemical properties when used in food products. The purpose of this study was to increase the nutritional value of rice bran with solid state fermentation using Rhizopus oryzae FNCC 6011 in tray bioreactor at $30^{\circ} \mathrm{C}$ for $120 \mathrm{~h}$. The results showed an increase in protein, fat and ash content by $58.5 \%, 124.5 \%$, and $18.6 \%$, respectively, while carbohydrate and fiber content decreased respectively by $25.6 \%$ and $51.2 \%$. The deceleration model successfully depicts the profile of biomass growth and improved protein. The kinetic parameters obtained $k, A$, and $Y_{P x}$ were $0.0536 / \mathrm{h}, 5.2537$, and $0.1821 \mathrm{~g} / \mathrm{g}$, respectively.
\end{abstract}

\section{Introduction}

Rice bran is a layer of rice grain wrap (layer of aleuron/epidermis) that is released during paddy rice milling process. The total grinding yield of rice bran about $10 \%$ [1]. About $90 \%$ of the resulting rice bran is used as animal feed at a low price and the remaining $10 \%$ is extracted into rice bran oil [2]. Rice bran is a source of protein, fatty acids, minerals, dietary fiber, and vitamin $\mathrm{E}$ (tocopherol and tocotrienol) as a source of antioxidants [3]. Rice bran also contains bioactive compounds such as inositol, inositol hexaphospat, ferulic acid, gamma oryzanol, and sterols that are proven to prevent cancer, hyperlipidemia, liver fat, hypercalciuria, kidney stones, and heart disease. With the discovery, rice bran has a huge potential to serve as a functional food [47].

Although rice bran is available abundantly, but application in food products is still very limited, this is because the content of macro and micro nutrient of rice bran is still strongly bound with fiber. To overcome these problems, the fermentation technology is required to improve the quality by utilizing microbes, yeasts, and fungi to decompose organic matter in substrates into simpler components. Fermentation technology can increase protein content in agricultural products and agro-industrial wastes through growth and activity of microbial metabolism [8-14]. Fermentation can also improve nutrients, aroma, flavor, and texture through enzymatic activity produced by microbes that can be used as functional food $[15,16]$.

Fermentation can be divided into two methods, submerged fermentation/liquid state fermentation and solid state fermentation. In recent years, many researchers have shown that solid state fermentation has a major impact on productivity, higher yields and improved product characteristics compared to liquid state fermentation $[17,18]$. Solid state fermentation is defined as fermentation involving solids in the absence of free water. Solid state fermentation benefits include lower energy requirements, less waste water, and environmentally friendly $[19,20]$.

Rhizopus oryzae is a filamentous fungi of the Zygomycetes class. Most strains of Rhizopus oryzae are isolated as active components in the production of food or alcoholic beverages in Indonesia, China and Japan. Rhizopus oryzae has long been used for the production of enzymes (glucoamylase and lipase), organic acid synthesis, and various fermentation applications in foodstuffs [21]. Various types of enzymes produced by various strains of Rhizopus oryzae include cellulase which serves to break down cellulose into oligosaccharides, glucose or other compounds. Another enzyme produced is xylanase which catalyzes the hydrolysis of 1-4-beta-D-glycosidic on xylans which is the constituent of hemicellulose, pectinase which serves to break down pectin into simple sugars, and amylase [22-27].

\footnotetext{
*Corresponding author: siswo.sumardiono@che.undip.ac.id
} 
To develop the potency of rice bran into a larger scale of production, a kinetic model that plays an important role in monitoring and predicting the results of the fermentation process is needed. The unstructured model is simpler because cell biomass is viewed as a single component without the internal dynamics of the cell so that the rate of reaction depends only on the phase conditions in the reactor, while structured models incorporate internal cell factors such as changes in biomass composition, so the model is more complex [28-31]. The kinetic equation is chosen based on the most appropriate regression result. Some kinetic models in solid state fermentation include linear, logistic, exponential, and deceleration models [32-34].

This research aims to determine the characteristics of fermented rice bran and determine the appropriate kinetics model to describe the growth profile of biomass and increase protein content in rice bran by solid state fermentation method for further industrial application.

\section{Materials and Methods}

\subsection{Rice bran}

Rice bran was obtained from rice mill in Teter Village, Simo Subdistrict, Boyolali Regency, Central Java, Indonesia. The rice bran is sieved using a 35 mesh sieve (Retsch AS200, Haan, Germany) to separate impurities such as rice husk and rice. The rice bran was packed in polypropylene box and stored at $4^{\circ} \mathrm{C}$ until used.

\subsection{Inoculum preparation}

Rhizopus oryzae (FNCC 6011) in the form of ampoule was obtained from Food and Nutrition Culture Collection (FNCC) of Food and Nutrition PAU of Gadjah Mada University, Indonesia. The cultures were transferred in a petri dish that has been filled with potato dextrose agar medium (PDA, Merck KGaA, Darmstadt, Germany) and incubated at $30^{\circ} \mathrm{C}$ for 7 days [35]. The spores that were formed were taken and dissolved in Tween 80 (0.2\%) (Merck KGaA, Darmstadt, Germany). Spore concentration was measured using TPC (total plate count) method. Spore suspension being stored at $4^{\circ} \mathrm{C}$.

\subsection{Fermentation}

Rice bran was fermented in solid state fermentation method using tray bioreactor, with dimensions of $16 \mathrm{~cm}$ $x 8 \mathrm{~cm} x 4 \mathrm{~cm}$. The rice bran (100 gr) was placed in tray bioreactor with a thickness of $2 \mathrm{~cm}$ substrate layer. The tray bioreactor containing the rice bran was sterilized in an autoclave (Hirayama HVE-50, Tokyo, Japan) at $121^{\circ} \mathrm{C}$ for 30 minutes. Take a sample of $\pm 2 \mathrm{~g}$ for protein analysis. Then into the rice bran substrate added $45 \mathrm{ml}$ of nutrient solution $\left(\mathrm{KH}_{2} \mathrm{PO}_{4} 2 \mathrm{~g} / \mathrm{l}, \mathrm{MgSO}_{4}\right.$ $1 \mathrm{~g} / \mathrm{l}$, and $\left(\mathrm{NH}_{4}\right) \mathrm{SO}_{4} 8 \mathrm{~g} / \mathrm{l}$ in $0.4 \mathrm{~N} \mathrm{HCl}$ ) (Merck KGaA, Darmstadt, Germany) [36].

The Rhizopus oryzae spore suspension was added to the substrate with a concentration of $4 \times 10^{6}$ spores/g of rice bran [35]. Sterile aquadest was then added until the moisture content of the substrate reached 55\% [37]. The rice bran was incubated in an incubator (Memmert IN55, Schwabach, Germany) at $30^{\circ} \mathrm{C}$ for 120 hours [37,38]. Samples were taken every 24 hours for biomass and protein content analyses

\subsection{Proximate composition}

The moisture, ash, and fat content were determined by the gravimetric method according to the AOAC (2000) recommendation. The total protein content was determined as total nitrogen by Kjeldahl method [39]. The conversion factor used is 6.25 . The crude fibers were determined through gravimetrical measurement of the residue obtained by the acid and basic digestion of the samples according to NDF method.

\subsection{Biomass determination}

Samples of $1 \mathrm{gr}$ was ground until smooth and then put into a centrifuge tube. Add $5 \mathrm{ml}$ of $15 \% \mathrm{Na}_{2} \mathrm{SO}_{4}$ solution (Merck KGaA, Darmstadt, Germany), then centrifuged at $12000 \mathrm{rpm}$ for 15 minutes (LaboGene 1730R, Alleroed, Denmark). After centrifugation there will be three layers, the top layer is biomass, the middle layer is the $\mathrm{Na}_{2} \mathrm{SO}_{4}$ solution and the bottom layer is the substrate. The biomass is then separated by a filter paper of Whatman 42 (Merck KGaA, Darmstadt, Germany) that has been known to weigh. The same is done for substrate. Then the filter paper contains biomass and the substrate is dried in an oven (Heraeus T6060, Hanau, Germany) at $40^{\circ} \mathrm{C}$ until a constant weight is obtained [40]. The results of measurement of dry weight of biomass using the following formula [32],

$$
X=\frac{x}{x+S+W}
$$

\subsection{Kinetics model}

Some models of kinetics of biomass growth in solid state fermentation include linear, exponential, logistic, and deceleration models [32-34].

\subsubsection{The linear model}

It is the simplest model in which the change in the biomass concentration over time is constant according to the equation

$$
\frac{d X}{d t}=k
$$

The result of the integration of the above equation becomes

$$
X=X_{0}+k t
$$

\subsubsection{The exponential model}

The Exponential model expression of biomass growth is

$$
\frac{d X}{d t}=\mu X
$$


The result of the integration of the above equation becomes

$$
X=X_{0} e^{\mu t}
$$

\subsubsection{The logistic model}

The logistic model is the most widely used model (75\%) to describe the solid state fermentation kinetics, while $25 \%$ is the other model [33].

$$
\frac{d X}{d t}=\mu X\left(1-\frac{X}{X_{m}}\right)
$$

The result of integration of the above equation is obtained

$$
X=\frac{X_{m}}{1+\left(\frac{X_{m}}{X_{0}}-1\right) e^{-\mu t}}
$$

\subsubsection{The deceleration model}

The deceleration model of biomass growth as follows,

$\frac{d X}{d t}=k A X e^{-h t}$

The result of the integration of the above equation becomes

$$
X=X_{0} \exp \left(A\left(1-e^{-\mathrm{ht}}\right)\right)
$$

\subsection{Model of protein formation}

Changes in protein content that has been formed during the fermentation process is determined using the following equation $[32,41]$,

$$
\frac{d P}{d t}=Y_{P X} \frac{d X}{d t}+m_{p} X
$$

\section{Results and Discussion}

The nutrition content of unfermented rice bran and fermented rice bran are presented in Table 1 below. Carbohydrate, protein, fat, and ash content are calculated on a dry basis.

Table 1. Nutrition content of rice bran

\begin{tabular}{|l|c|c|}
\hline \multicolumn{1}{|c|}{ Component } & $\begin{array}{c}\text { Unfermented } \\
\text { Rice bran }\end{array}$ & $\begin{array}{c}\text { Fermented } \\
\text { Rice bran }\end{array}$ \\
\hline Carbohydrate (\%) & $68.28 \pm 0.15$ & $50.79 \pm 0.18$ \\
Fiber (\%) & $26.51 \pm 0.11$ & $12.94 \pm 0.08$ \\
\hline Protein (\%) & $12.59 \pm 0.07$ & $19.95 \pm 0.09$ \\
\hline Fat (\%) & $6.21 \pm 0.04$ & $13.94 \pm 0.06$ \\
\hline Ash (\%) & $12.92 \pm 0.04$ & $15.32 \pm 0.03$ \\
\hline
\end{tabular}

Values are expressed as means \pm standard deviation
Based on Table 1 it can be seen that after fermentation for 120 hours there was a decrease of carbohydrate and fiber content respectively $25.6 \%$ and $51.2 \%$, this is due to activity of Rhizopus oryzae metabolism that grow and developed in rice bran. Rhizopus oryzae produces enzymes used to break down polysaccharides such as cellulase, xylanase, pectinase, and amylase to oligosaccharides and glucose, resulting in reduced carbohydrate and fiber content $[22,23,25,26,42]$.

Glucose from polysaccharide splitting as a source of energy in the cell metabolism Rhizopus oryzae produces a number of biomass and extracellular compounds such as enzymes that result in increased protein content in rice bran. $10-25 \%$ of the fungus constituents are proteins $[14,43]$. Protein content in fermented rice bran has an increase of $58.5 \%$. Several authors have reported increase in protein in fermented rice bran by $40 \%$, $53.4 \%$, and $49.3 \%[35,36,38]$. The increase in protein content in this study is higher than previous studies because in this study the rice bran used has particles sizes smaller than $0.42 \mathrm{~mm}$, while in previous research using rice bran with particles sizes between 0.35 and $0.60 \mathrm{~mm}$. The smaller particle diameters will produce higher protein content due to the oxygen transfer rate, heat transfer rate, and transfer rate of metabolic gases during the fermentation process are in optimal conditions for biomass growth and excretion of extracellular enzymes [36].

Fat content in fermented rice bran has an increase of $124.5 \%$, this is due to the growing biomass Rhizopus oryzae more and more. The constituents of cell wall and plasma membrane of Rhizopus oryzae is fat component in the form of phospolipid and lipoprotein so that fat content in fermented rice bran is increased [43]. Increased fat content in fermented rice bran is also reported by $17.3 \%$ after 60 hours of fermentation. The results are much lower than this study, this is because the bran used has particles sizes between 0.39 and 1.67 $\mathrm{mm}$ so it is still mixed with broken rice and rice husk. This will affect the increase in fat content obtained. The smaller the rice bran particles will produce higher fat content in the fermentation process [44].

While the ash content in fermented rice bran has an increase of $18.6 \%$. This result is consistent with some researchers who reported an increase in ash content by $30 \%, 47.8 \%$, and $10.5 \%[35,38,45]$. Increased ash content is thought to result from the growth of hypha and mycelium Rhizopus oryzae on the rice bran. Rhizopus oryzae cell wall contains several minerals such as phosphorus, potassium, sodium and sulfur, resulting in ash content in the fermented rice bran has increased $[35,43]$. The same phenomenon also occurs in rice bran fermentation using Rhizopus oligosporus and Saccharomyces cerevisiae where ash content increases by $24.5 \%$ after 48 hours of fermentation [46]. Fungal ash content varies from $1 \%$ to $29 \%$ depending on species of fungus and growth conditions [47].

To develop the potency of rice bran into a larger scale of production, the kinetic model is required. Regression analysis is used to determine the most 
appropriate kinetic equation and the values of the parameter of this equation that give the best fit to the experimental data. The results of matching experimental data with the model are presented in the Table 2 and Figure 1 below.

Table 2. Biomass growth model

\begin{tabular}{|c|c|c|}
\hline Model & Equation & $\begin{array}{c}\text { Sum of square of } \\
\text { residuals (SSR) }\end{array}$ \\
\hline Linear & $\frac{d X}{d t}=0.0021$ & 0.0027 \\
\hline Exponential & $\frac{d X}{d t}=0.0437 X$ & 0.0220 \\
\hline Logistic & $\frac{d X}{d t}=0.1920 X\left(1-\frac{X}{0.1897}\right)$ & 0.0030 \\
\hline Deceleration & $\frac{d X}{d t}=0.0536 \times 5.2537 \times X e^{-0.0536 t}$ & 0.0008 \\
\hline
\end{tabular}

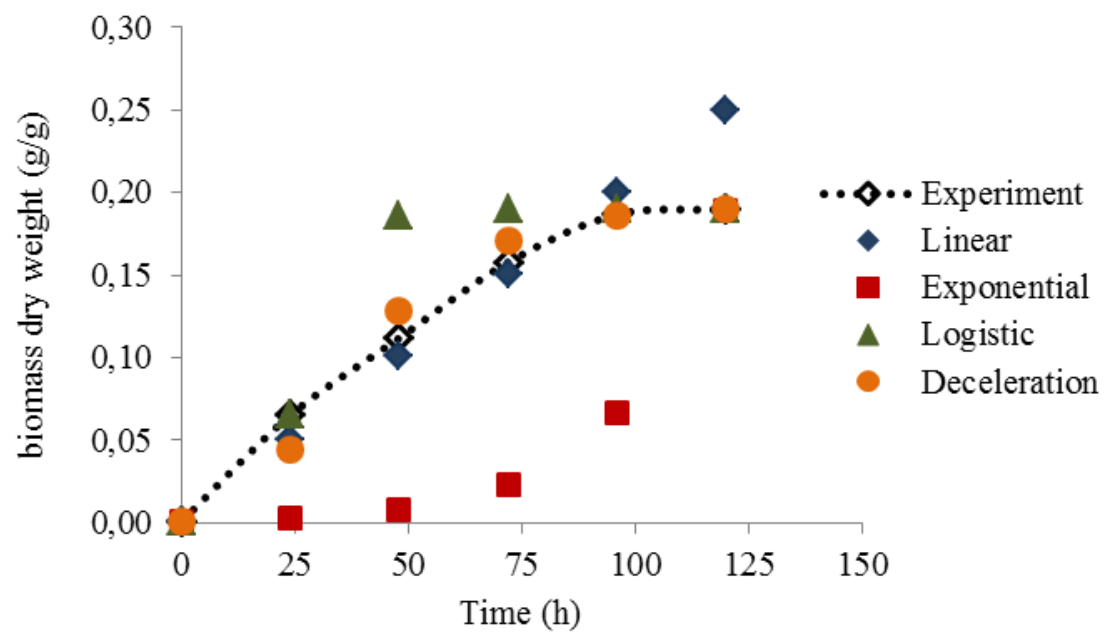

Fig 1. Biomass growth model

From the above kinetic models closest to the experimental data is the deceleration model where each point in the deceleration model coincides with the experimental data, it can also be seen from the smallest sum of square of residuals (SSR) value of 0.0008 , so the deceleration model is best suited to describe the biomass growth model of fermented rice bran [32-34]. The kinetic parameters obtained are $\mathrm{k}$ (biomass growth rate constant) of $0.0536 / \mathrm{h}$ and the pre-exponential factor of 5.2537. The deceleration model for growth kinetics of biomass is also used to describe the growth profile of Rhizopus oligosporus using cassava starch substrate in solid state fermentation medium. Model matching results with experimental data resulted in the smallest sum of square of residuals of 0.0626 compared to linear, exponential and logistic models. The kinetic parameter obtained is $\mathrm{k}$ (biomass growth rate constant) of $0.044 / \mathrm{h}$. [33,48,49].

The deceleration model on the growth of biomass is used to integrate the product formation equation, so that the following equation is obtained at equation 11. From the calculation result using Ms. excel solver program obtained parameters $\mathrm{Y}_{\mathrm{PX}}=0.1821$ $\mathrm{g} / \mathrm{g}$ and $\mathrm{m}_{\mathrm{P}}=0$. The results of experimental protein content curve with the model are depicted in the Figure 2.

$P=P_{0}+\left[Y_{P X}\left(k \cdot A\left(X_{0} \exp \left(A\left(1-e^{-k t}\right)\right) e^{-k t}\right)\right)+m_{p}\left(X_{0} \exp \left(A\left(1-e^{-k t}\right)\right)\right)\right]$ 


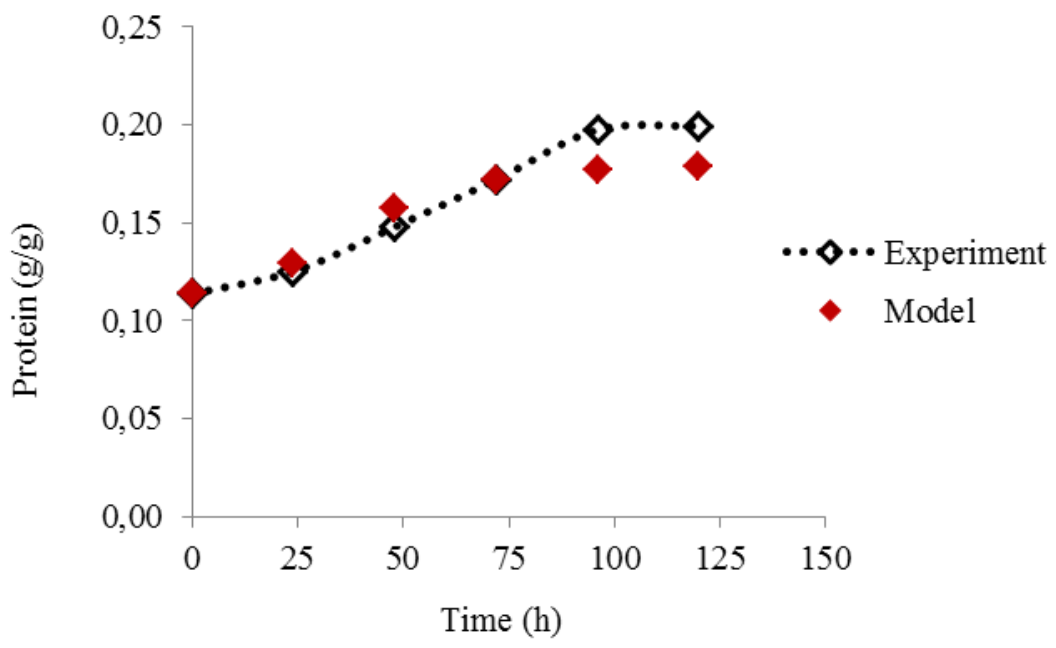

Fig 2. Model increased protein content

The data of experimental results with the model coincide and has a significant proximity between points that the model is acceptable. The kinetic equation of protein formation,

$\frac{d P}{d t}=0.1821 \frac{d X}{d t}$

Deceleration model is also used to describe the production of protein from bagasse using Chaetomium cellulolyticum through solid state fermentation method. The results of model calculations with experimental data show a significant proximity [50].

\section{Conclusions}

The protein, fat, and ash content in fermented rice bran have increased by $58.5 \%, 124.5 \%$, and $18.6 \%$, respectively, while carbohydrate and fiber content decreased respectively by $25.6 \%$ and $51.2 \%$. The deceleration model successfully depicts the profile of biomass growth and improved protein well. The kinetic parameters obtained $\mathrm{k}, \mathrm{A}$, and $\mathrm{Y}_{\mathrm{PX}}$ were $0.0536 / \mathrm{h}, 5.2537$, and $0.1821 \mathrm{~g} / \mathrm{g}$ respectively. This research makes the fermented rice bran has a great potential to be utilized as a functional foodstuff.

\section{Symbols}

W moisture content in the sample $(\mathrm{g})$

$\mathrm{x} \quad$ dry weight of biomass ( $\mathrm{g}$ )

S dry weight of the substrate $(\mathrm{g})$

$\mathrm{X}$ biomass concentration $(\mathrm{g} / \mathrm{g})$

$\mathrm{X}_{\mathrm{o}} \quad$ initial biomass concentration $(\mathrm{g} / \mathrm{g})$

$\mathrm{X}_{\mathrm{m}} \quad$ maximum biomass concentration $(\mathrm{g} / \mathrm{g})$

$\mathrm{t}$ time $(\mathrm{h})$

$\mathrm{k} \quad$ growth rate constant of biomass $\left(\mathrm{h}^{-1}\right)$

$\mu \quad$ specific growth rate of biomass $\left(\mathrm{h}^{-1}\right)$

A pre-exponential factor
$\mathrm{Y}_{\mathrm{PX}} \quad$ yield product (protein) to biomass $(\mathrm{g} / \mathrm{g}$ )

$\mathrm{m}_{\mathrm{p}} \quad$ maintenance coefficient of product formation (g/g.h)

\section{Acknowledgments}

Authors thank to Department of Chemical Engineering, Diponegoro University for all facilities to do this research.

\section{References}

1. W. Hu, J. Henry, T. Shin, I.S. Godber. JAOCS 73, 1653 (1996)

2. R. Schramm, A. Abadie, N. Hua, Z. Xu, M. Lima, J. Biol. Eng 9, 1 (2007)

3. Z. Xu, N Hua, J.S. Godber, J. Agric. Food. Chem 49, 2077 (2001)

4. R.J. Jariwalla, Drugs. Exp. Clin. Res 27, 17 (2001)

5. S. Khatoon, A.G. Gopalakrishna. JAOCS 81, 939 (2004)

6. Ardiansyah, H. Shirakawa, T. Koseki, K. Ohinata, K. Hazhizume, M Komai, J. Agric. Food. Chem 54, 1914 (2006)

7. E.A. Salehi, M. Sardarodiyan, Biochem. Ind. J 10, 101 (2016)

8. P. Daubresse, S. Ntibashirwa, A. Gheysen, J.A. Meyer, Biotechnol. Bioeng 29, 962 (1987)

9. C.R. Soccol, I. Iloki, B. Marin, M. Raimbault, J. Food. Sci. Technol 31, 320 (1994)

10. S.O. Aro, Afr. J. Biotechnol 7, 4789 (2008)

11. H.S. Hamdy, Roum. Biotechnol. Lett 18, 7929 (2013)

12. T.C. Do Santos, G.A. Diniz, A.R. De Brito, A.J.V. Pires, M. Fanco, Rev. Caatinga. Mossoró 28, 248 (2015)

13. C. Sriherwanto, B. Santoso, A. Mahsunah, I. Sujai, S. Toelak, M. Rusmiyati, JBBI 3, 72 (2016) 
14. J.A. Adejuyitan, E.T. Otunola, I.F. Bolarinwa, B.F. Olanipekun, J. Food. Chem. Nanotechnol 3, 19 (2017)

15. E. Badiale-Furlong, J.L.M. Cacciamani, J. Garda-Buffon, Braz. J. Food. Technol 10, 233 (2007)

16. C.M. Da Silveira, E. Badiale-Furlong, Braz. Arch. Biol. Technol 52, 1555 (2009)

17. S. Martins, S.I. Mussatto, G. Martínez-avila, J. Montañez-saenz, C.N. Aguilar, J.A. Teixeira, Biotechnol. Adv 29, 365 (2011)

18. G.H Hansen, M. Lubeck, J.C. Frisvad, P.S. Lubeck, B. Andersen, Process. Biochem 50, 1327 (2015)

19. A. Pandey, Biochem. Eng. J 13, 81 (2003)

20. L. Thomas, C. Larroche, A. Pandey, Biochem. Eng. J 81, 146 (2013)

21. J.A. Mertens, C.D. Skory, A.S. Ibrahim, Arch. Microbiol 186, 41 (2006)

22. R.C. Yu, Y.D. Hang, World. J. Microbiol. Biotechnol 6, 15 (1990)

23. U. Bakir, S. Yavascaoglu, F. Guevenc, A. Ersayin, Enzyme. Microb. Technol 29, 328 (2001)

24. H.S. Hamdy, IJBT 5, 284 (2006)

25. P. Chellapandi, H.M. Jani, Braz. J. Microbiol 39, 122 (2008)

26. M. Karmakar, R.R. Ray, Res. J. Microbiol 6, 41 (2011)

27. Y.X. Zheng, Y.L. Wang, J. Pan, J.R. Zhang, Y. Dai, K.Y. Chen, Bioresour. Technol 241, 1138 (2017)

28. J.E. Bailey, D.F. Ollis. Biochemical Engineering Fundamentals (McGraw-Hill Book Company, New York, 1987)

29. M.C. Del Barrio, R.B. Demafelis, S.M. Mercado, J.L. Movillon, C.M. Rebancos, Philipp. Agric. Scientist 95, 129 (2012)

30. J. Almquist, M. Cvijovic, V. Hatzimanikatis, J. Nielsen, M. Jirstrand, Metab. Eng 24, 38 (2014)

31. J.A.G. Rueda, V.A.L. Gonzales, M.A.O. Supelano, J.A.P. Mendoza, C.G. Luna, L.J.L. Giraldo, Cienc. Tecnol. Futuro 6, 81 (2015)

32. D.A. Mitchell, N. Krieger, M. Berovic. SolidState Fermentation Bioreactor: Fundamental of Design and Operation (Springer-Verlag, Germany, 2006)
33. G. Viccini, D.A. Mitchell, S.D. Boit, J.C.S Gern, A. da Rosa, R.M. Costa, F.D.H. Dalsenter, F.O. von Meien, N. Krieger, Food. Technol. Biotechnol 39, 271 (2001)

34. G. Viccini, D.A. Mitchell, N. Krieger, Food Technol. Biotechnol 41, 191 (2003)

35. M.D. Oliveira, V. Feddern, L. Kupski, E.P. Cipolatti, E. Badiale-Furlong, L.A. de SouzaSoares, Cyta. J. Food 8, 229 (2010)

36. C.G. Schmidt, E.B. Furlong, Bioresour. Technol 123, 36 (2012)

37. F.N. Yunus, M. Nadeem, F. Rashid, J. Inst. Brew 121, 553 (2015)

38. L. Kupski, E. Cipolatti, M. Da Rocha, M.S. Oliveira, L.A. Souza-Soares, E. BadialeFurlong, Braz. Arch. Biol. Technol 55, 937 (2012)

39. AOAC. Official Methods of Analysis $17^{\text {th }}$ (Washington DC, 2000)

40. A. Augustine, I. Joseph, R.P. Raj, J. Mar. Biol. Ass. India 48, 139 (2006)

41. D. Mazaheri, S.A. Shojaosadati, Iran. J. Biotechnol 11, 156 (2013)

42. R. Ravinder, L.V. Rao, P. Ravindra, Food. Technol. Biotechnol 41, 243 (2003)

43. M.L. Shuler, F. Kargi. Biopreocess Engineering Basic Concepts (Prentice-Hall International Inc, New Jersey, 2002)

44. K.C.Massarolo, T.D. De Souza, A.C. Ribeiro, E.B. Furlong, L.A. De Souza Soares, Biocatal. Agric. Biotechnol 8, 204 (2016)

45. V. Feddern, E.B. Furlong, L. Almeida, S. Soares, Ciênc. Tecnol. Aliment. Campinas 27, 800 (2007)

46. O.O Odugawa, M.O. Edema, A.O. Ayeni, Bioresour. Technol 99, 1816 (2008)

47. D.H. Griffin. Fungal physiology (John Wiley \& Sons, New York, 1994)

48. D.A. Mitchell, D.D. Do, P.F. Greenfield, H.W.A. Doelle, Biotechnol. Bioeng 38, 353 (1991)

49. L. Ikasari, D.A. Mitchell, D.M. Stuart, Biotechnol. Bioeng 64, 722 (1999)

50. O. Bravo, A. Ferrer, C. Aieloo, A. Ledesma, M. Davila, Biotechnol. Lett 16, 865 (1994) 